\title{
A Note from the Editor-in-Chief, Deputy Editor, and Managing Editor
}

\author{
Vincent R. Bonagura • Jean-Laurent Casanova • \\ David W. Rosenthal
}

Published online: 26 February 2015

(C) Springer Science+Business Media New York 2015

To the readership of the Journal of Clinical Immunology:

With the publication of the article entitled "Coronin-1A: Immune Deficiency in Humans and Mice" in the February issue of the Journal, we begin our Journal of Clinical Immunology continuing medical education (CME) review program where readers can receive 1 AMA PRA Category 1 Credit $^{\mathrm{TM}}$ for each review article, granted by the Clinical Immunology Society (CIS). Readers wishing to receive CME credit should

David Rosenthal's primary affiliation is Department of Internal Medicine

V. R. Bonagura $(\varangle) \cdot$ D. W. Rosenthal

Laboratory for Host Defense, Jeffrey Modell Diagnostic Center,

Feinstein Institute for Medical Research, Manhasset, NY, USA

e-mail: VBonagura@NSHS.edu

V. R. Bonagura $\cdot$ D. W. Rosenthal

Departments of Pediatrics and Internal Medicine, Hofstra NS-LIJ

School of Medicine, Great Neck, New York, USA

V. R. Bonagura $\cdot$ D. W. Rosenthal

Alexandra and Steven Cohen Children's Medical Center of New

York, North Shore-LIJ Medical Center, Great Neck, New York, USA

\section{J.-L. Casanova}

St. Giles Laboratory of Human Genetics of Infectious Diseases,

Rockefeller Branch, The Rockefeller University, New York, NY, USA

\section{J.-L. Casanova}

Howard Hughes Medical Institute, New York, USA

\section{J.-L. Casanova}

Laboratory of Human Genetics of Infectious Diseases, Necker

Branch, Necker Hospital for Sick Children, Paris, France

\section{J.-L. Casanova}

Paris Descartes University, Imagine Institute, Paris, France

\section{J.-L. Casanova}

Pediatric Hematology-Immunology Unit, Necker Hospital for Sick Children, Paris, France read the article in this issue of the Journal, and answer the questions found on the CIS Journal CME web page, for each review:

http://www.clinimmsoc.org/education/continuingmedical-education/e-learning-tools/journal-cme

Achieving a score of $80 \%$ or higher will qualify for $1 \mathrm{CME}$ credit. We invite all of our readers interested in obtaining CME credits to enroll in this program. We are confident that you will enjoy this new feature of the Journal.

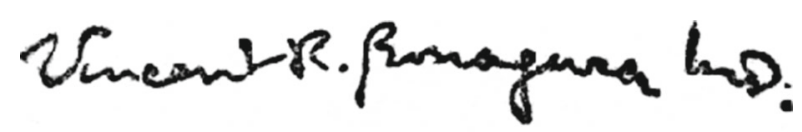

Vincent R. Bonagura MD

Editor-in-Chief

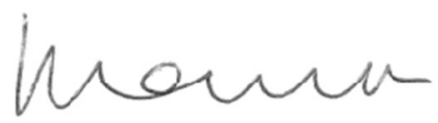

Jean-Laurent Casanova MD PhD

Deputy Editor

CME Series Editor

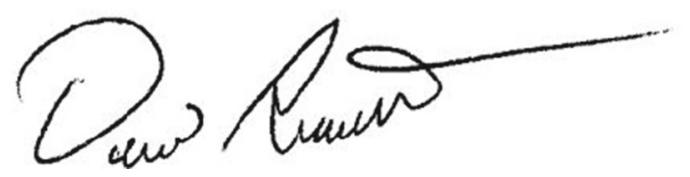

David W. Rosenthal, DO, PhD

Managing Editor 